\title{
HOUSE OPERA | OPERA HOUSE
}

\section{Mitch McEwen}

Assistant Professor of Architecture, Taubman College of Architecture and Urban Planning, University of Michigan, Detroit, USA
Marcelo López-Dinardi

\author{
Adjunct Assistant Professor, Barnard+Columbia \\ Architecture School, Columbia University, New York, USA
}

\author{
An Office \\ Detroit, Estados Unidos \\ 2015 \\ P
}

What value can architecture generate when there's no longer market value? After the 2008 crisis had caused the prices of homes in Detroit to drop to unusual levels, this project transforms a vacant house into a cultural infrastructure for the community. Understood as an opera, the house not only becomes a piece in itself, but also an urban strategy for the reconsideration of what we usually understand as the drama of deterioration and blight.

KEYWORDS · demolition, blight, vacancy, performance, drama

The House Opera | Opera House project seeks, through architectural innovation, to propose a fertile alternative to the binary of blight and demolition. Implications of the project at the urban planning level include: how can residential vacancy be converted into an opportunity to support local cultural assets? What are the zoning, planning and building code changes that make this possible? The project addresses these questions through a suite of spatial and material tactics to facilitate exploration of performance, community, and form. The experimental aspects architecturally include strategies of subtraction, programmatic collaboration, and expanded territories of adaptive re-use. The project seeks to explore what might occur when the borders of a house open up to annihilate the borders between art and community, makers and receivers of art, museums and home.

Inspired by the flexibility of uses for houses in Detroit, this project stages an opera as a house, the house and its dramas of occupancy and vacancy, demolition, and re-purposing, as an opera. As indicated in the title-House Opera | Opera House- the project pursues multiple relationships of physical structure to performance. Instigated by architectural designers working with a network of artists and curators, the House Opera | Opera House project situates built form in active relationship with choreography, costume, music, language, and drama. The doubling of the project's title warns that opera will be explored and mined as an art form as much as the house as a typology of building and program.

As a long-term project of architectural experimentation, House Opera | Opera House actively explores dynamics of public and 


\begin{tabular}{|c|}
\hline Arquitectos / Architects \\
\hline A(n) Office (anoffice.us) \\
\hline Arquitectos asociados / Associated architects \\
\hline McEwen Studio \\
\hline Colaboradores / Collaborators \\
\hline Tyrene Calvesbert, Rebecca Curtis, Ye Fu, Juan Martínez, Salam Rida \\
\hline Ubicación / Location \\
\hline 1620 Morrell St, Detroit, MI, USA \\
\hline Cliente / Client \\
\hline AFROTOPIA \\
\hline Ingeniería estructural / Structural engineering \\
\hline Sarah Millsaps Towles \\
\hline Contratista de obras / Building contractor \\
\hline Lands Friend Builders \\
\hline Materiales / Materials \\
\hline Madera, madera recuperada / Wood, reclaimed wood \\
\hline Terminaciones interiores y exteriores / \\
\hline Interior and exterior finishing materials \\
\hline $\begin{array}{l}\text { Envoltura Tyvek, madera recuperada, cobertura plástica Heat Shrink / } \\
\text { Tyvek wrapping, reclaimed wood, Heat Shrink construction Film }\end{array}$ \\
\hline Presupuesto / Cost \\
\hline USD $\$ 30,000$ \\
\hline Superficie construida / Built area \\
\hline $185,8 \mathrm{~m}^{2} / 2,000 \mathrm{ft}^{2}$ \\
\hline Superficie terreno / Site area \\
\hline $464,5 \mathrm{~m}^{2} / 5,000 \mathrm{ft}^{2}$ \\
\hline Año de Proyecto / Project year \\
\hline $2014-2015$ \\
\hline Año de construcción / Construction year \\
\hline 2015 \\
\hline Maquetas / Models \\
\hline$A(n)$ Office \\
\hline
\end{tabular}

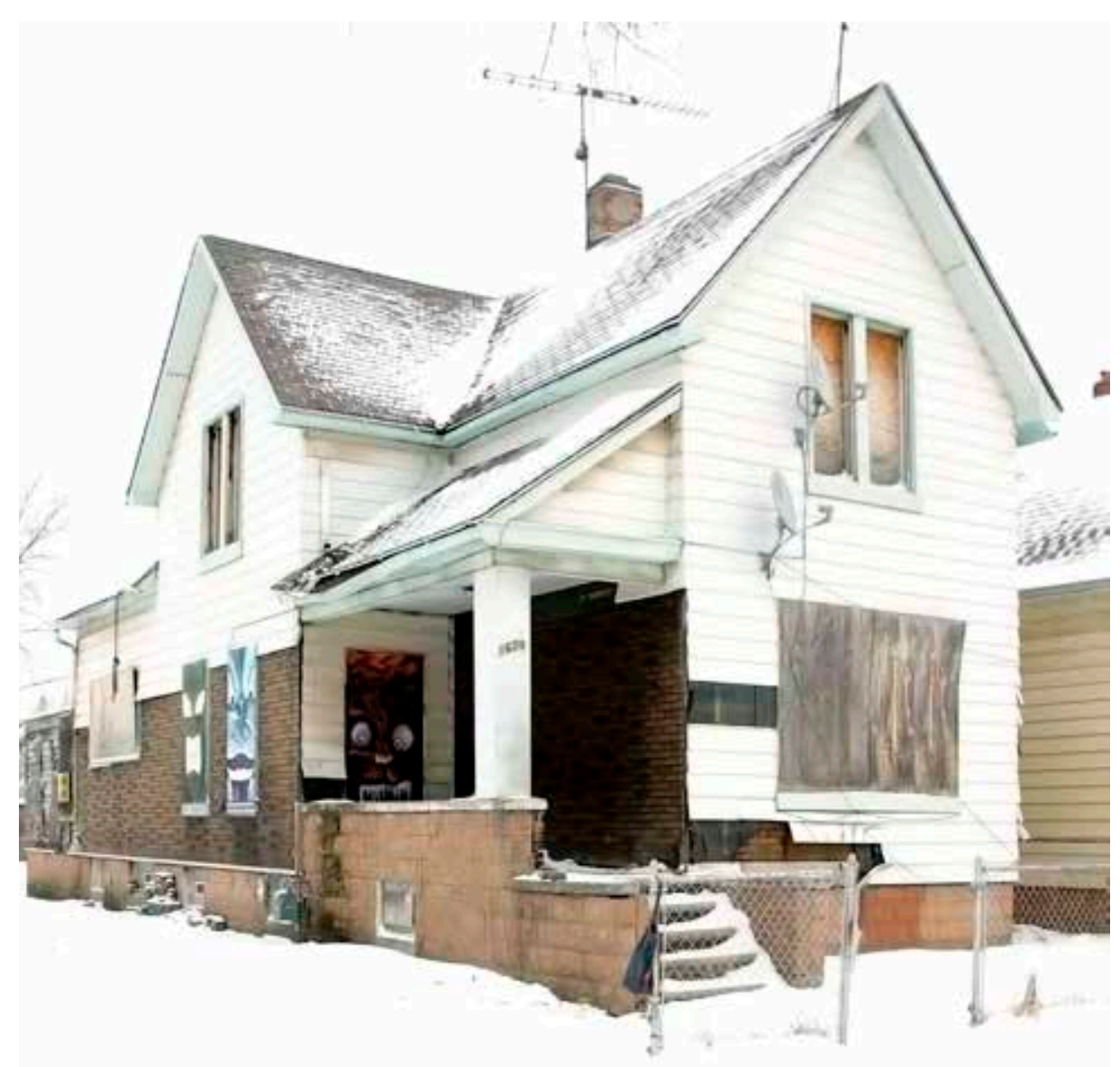

Condiciones previas, vista desde la calle / Previous conditions, view from the street $\odot$ Marcelo López-Dinardi

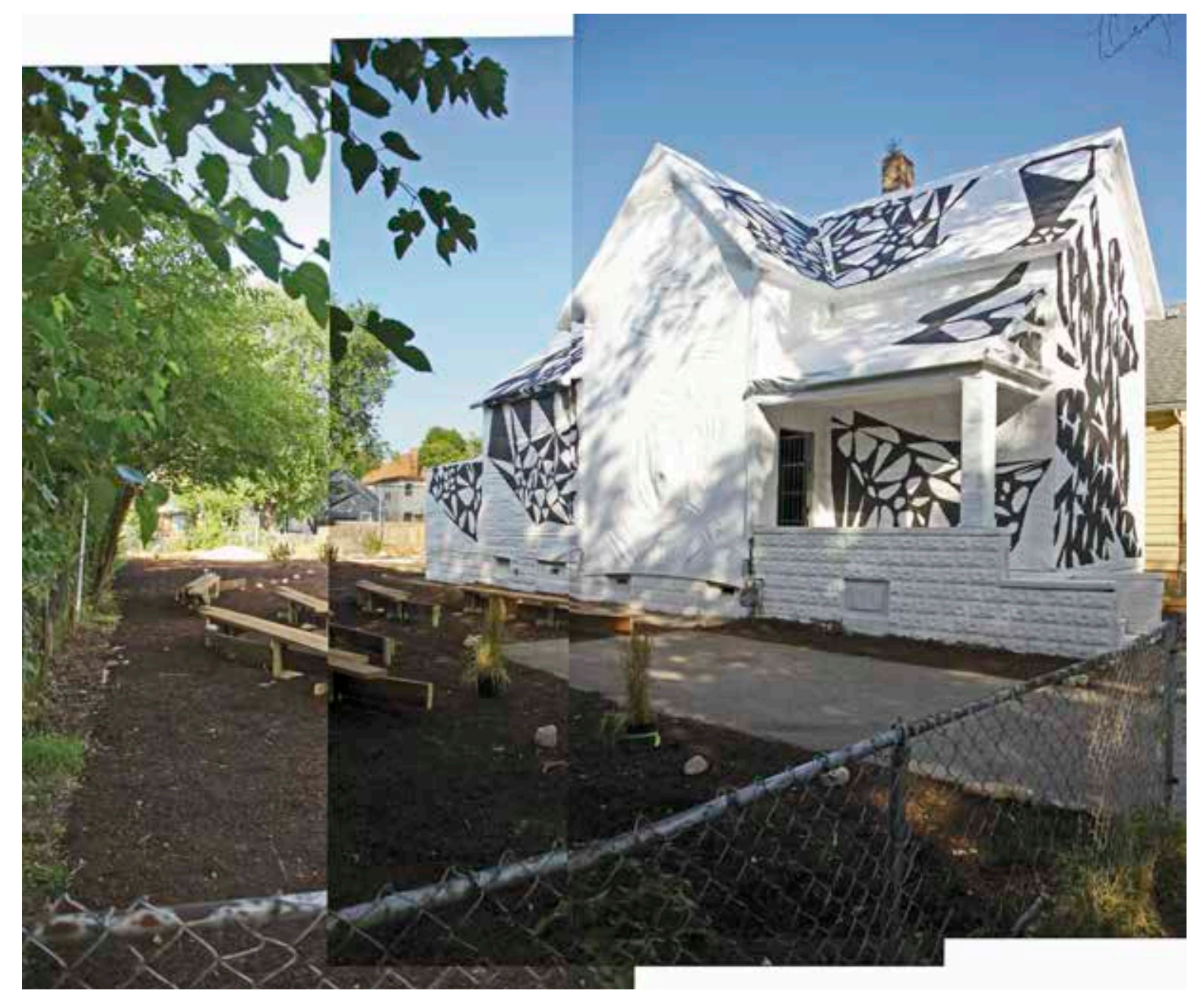

Vista exterior / Exterior view @ Marcelo López-Dinardi

OBRAS Y PROYECTOS $\mathbf{2 7}$ WORKS AND PROJECTS 


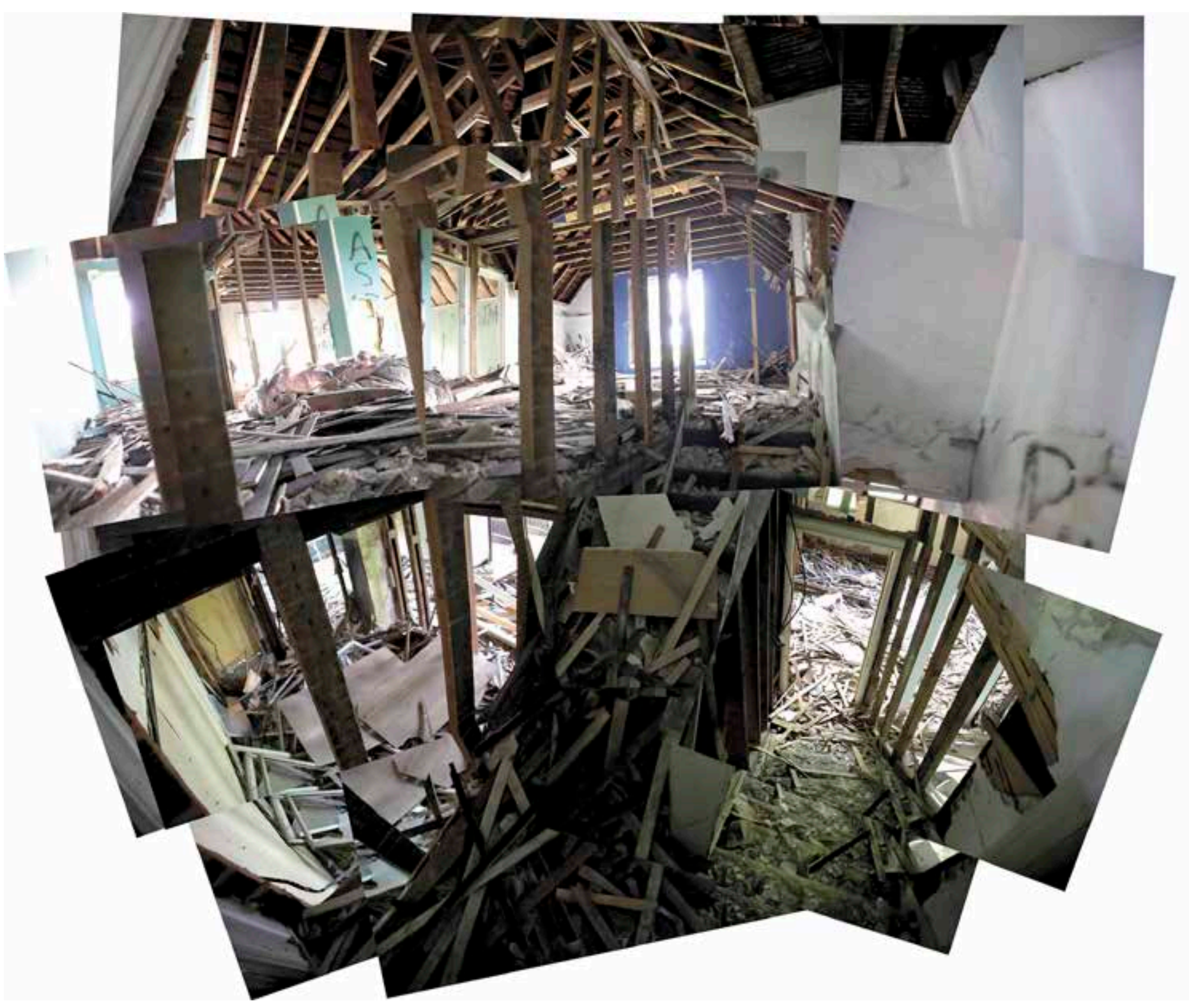

cultural engagement at the scale of the single family home. The title alludes as well to the "opera publica" of Rome, literally public works, which defined the state of the art of physical infrastructure roughly two millennia ago. House Opera |Opera House aims to open and produce new possibilities of public engagement for architecture as a discipline and for houses as a built typology, investigating the means by which a formerly vacant house may serve as a node of cultural infrastructure. As historian Reinhold Martin argues, infrastructure (financial, political or social) is what is reproduced and repeated. The House Opera | Opera House produces -and is product of-communal infrastructures.

The House Opera opened temporarily to the public on July $24-25$ with Sigifest, an arts, music and performance festival organized by AFROTOPIA, directed by Detroiter curator Ingrid Lafleur.

The House Opera | Opera House was originated by Mitch McEwen when McEwen Studio bought the house and received funding by grants from the Knight Foundation, Graham Foundation, University of Michigan Taubman College of Architecture and Urban Planning. The first phase of design-subtraction-build was achieved with support from individual donors through a crowdsourcing campaign with funds matched by the Michigan Economic Development Corporation. ARQ

www.houseopera.us 
Planta original primer piso

Existing first floor plan

E./ S. 1: 250

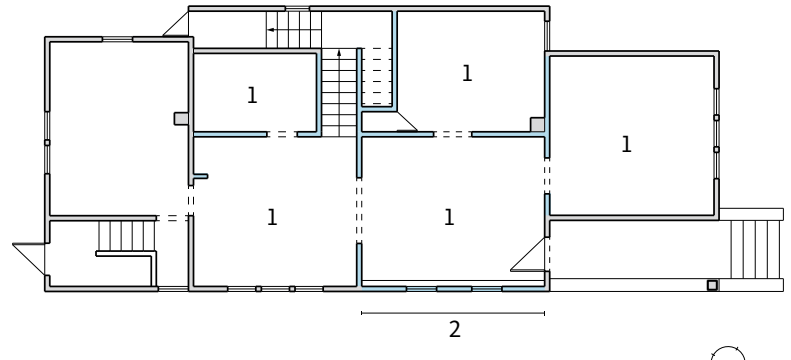

Q

Muro a mantener / Wall to remain

Muro, ventana, puerta o piso a remover / Wall, window, door or floor to be removed

\section{LEYENDA / LEGEND}

1. Cielo y estructura de segundo 2 Muro removido desde el piso removida / Removed ceiling primer piso al techo / Removed and second floor structure wall from first floor to roof

Planta de techos / Roof plan

E./ S. 1: 250

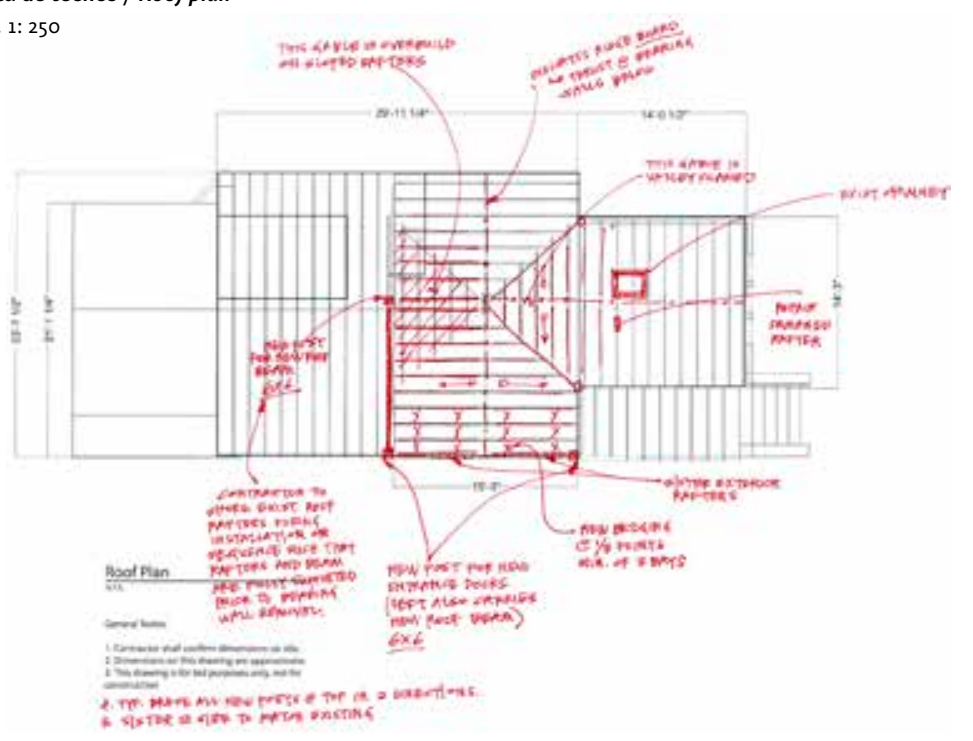

Elevación poniente original/

Existing west elevation

E./ S. 1: 250

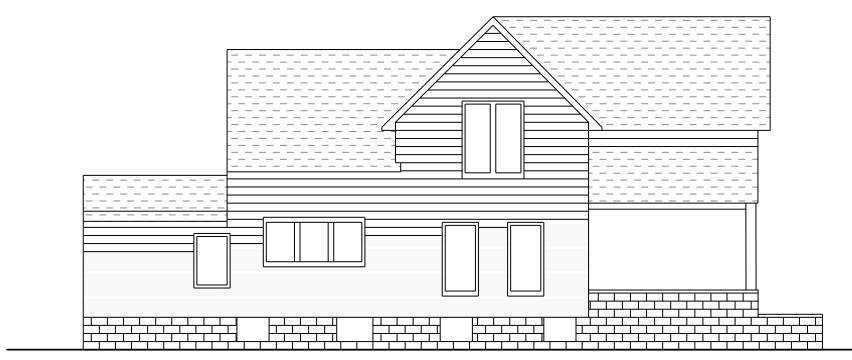

Revestimiento Tyvek / Tyvek surface

Elevación poniente propuesta

Proposed west elevation

E./ S. 1: 250

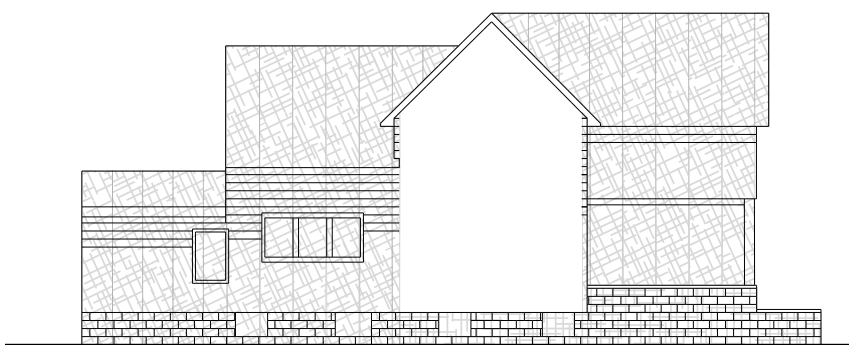

Axonométrica / Axonometric S. e. / N. s.

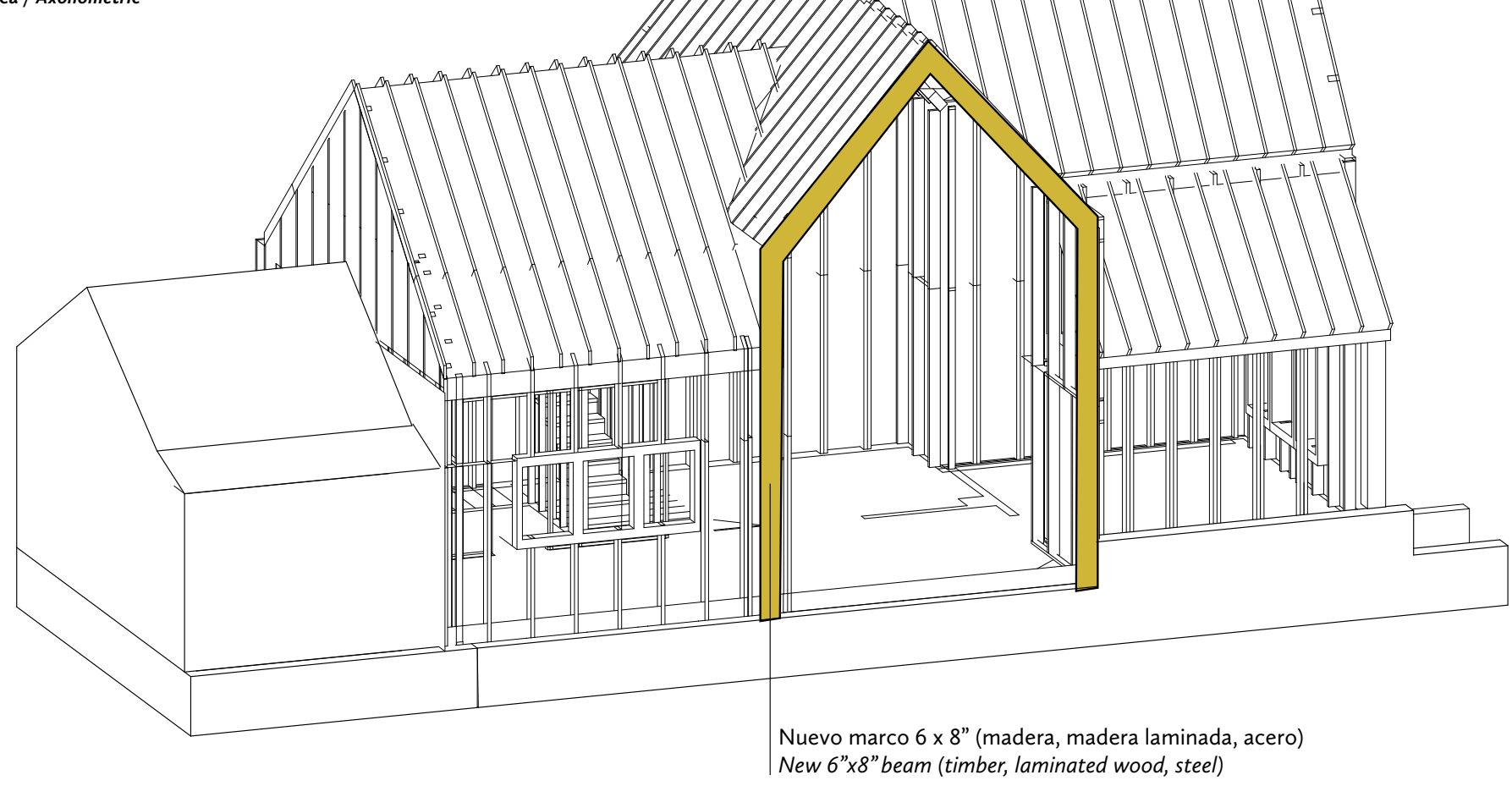



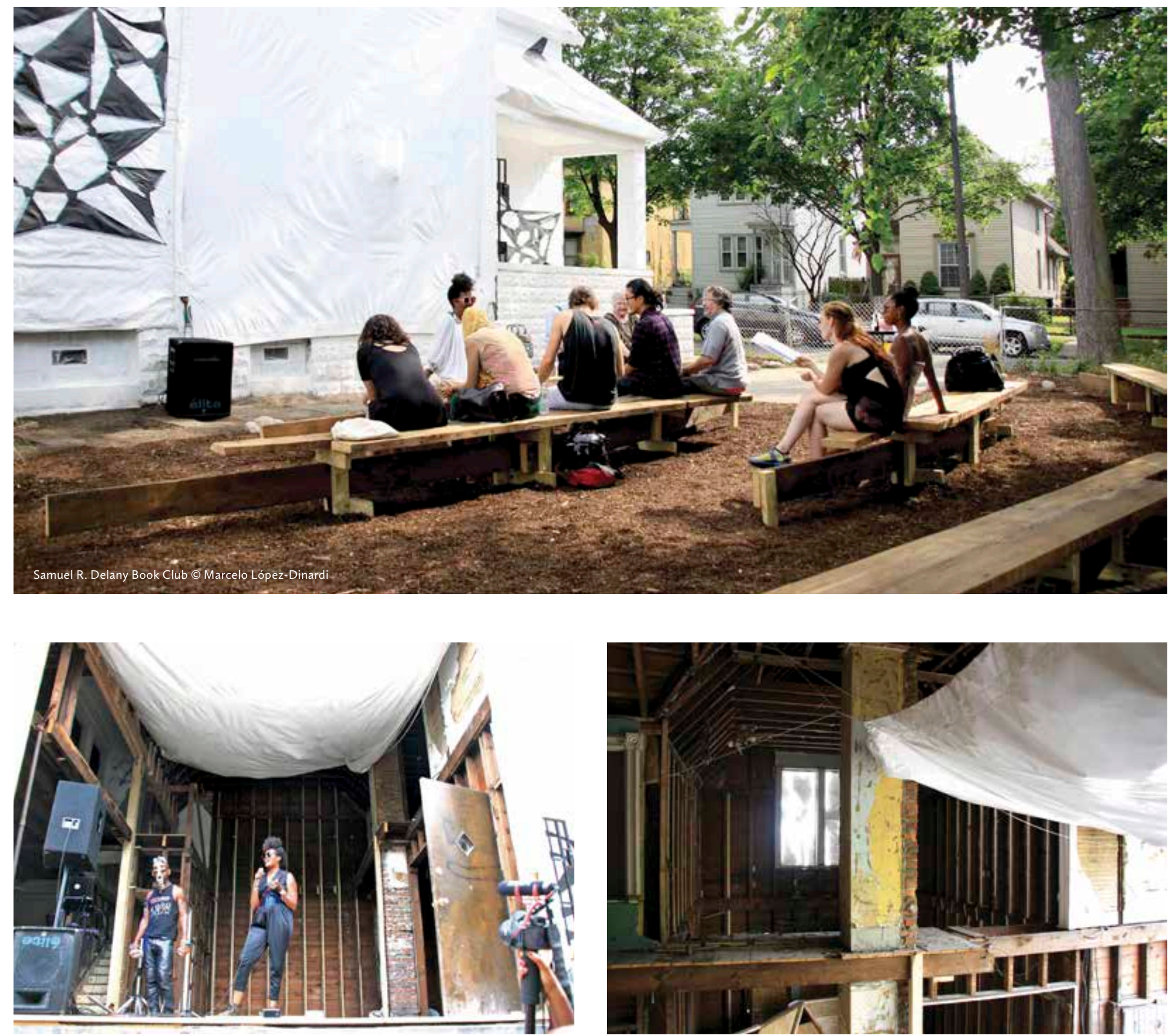

Ingrid Lafleur en el escenario abierto / Ingrid Lafleur at the open stage $\odot$ Marcelo López-Dinardi

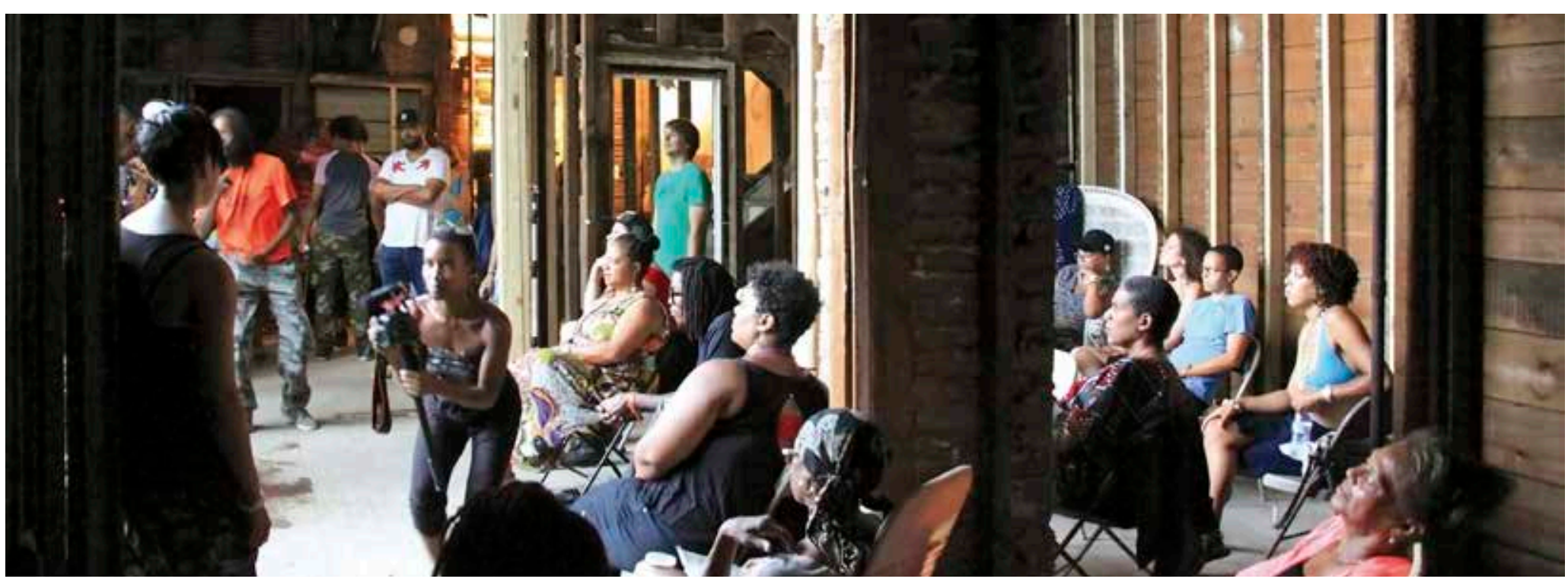

Público en el escenario / Audience on the stage $\odot$ Marcelo López-Dinardi 


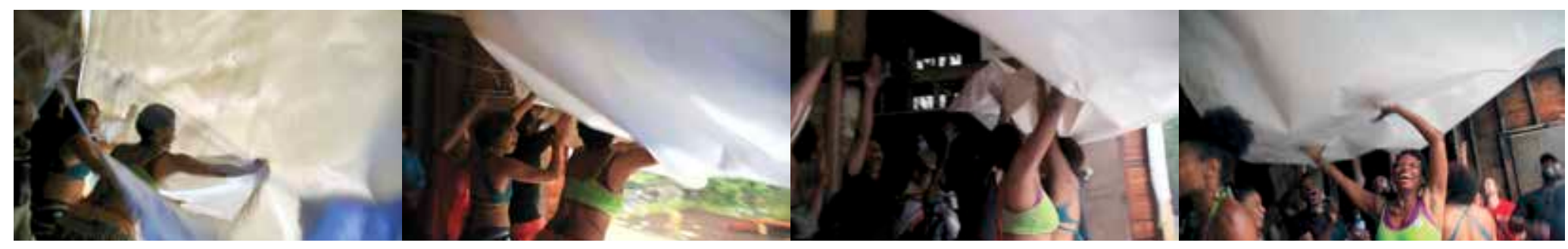

Cortina desplegándose hacia el exterior / Curtain folded-out to the exterior @ Marcelo López-Dinardi
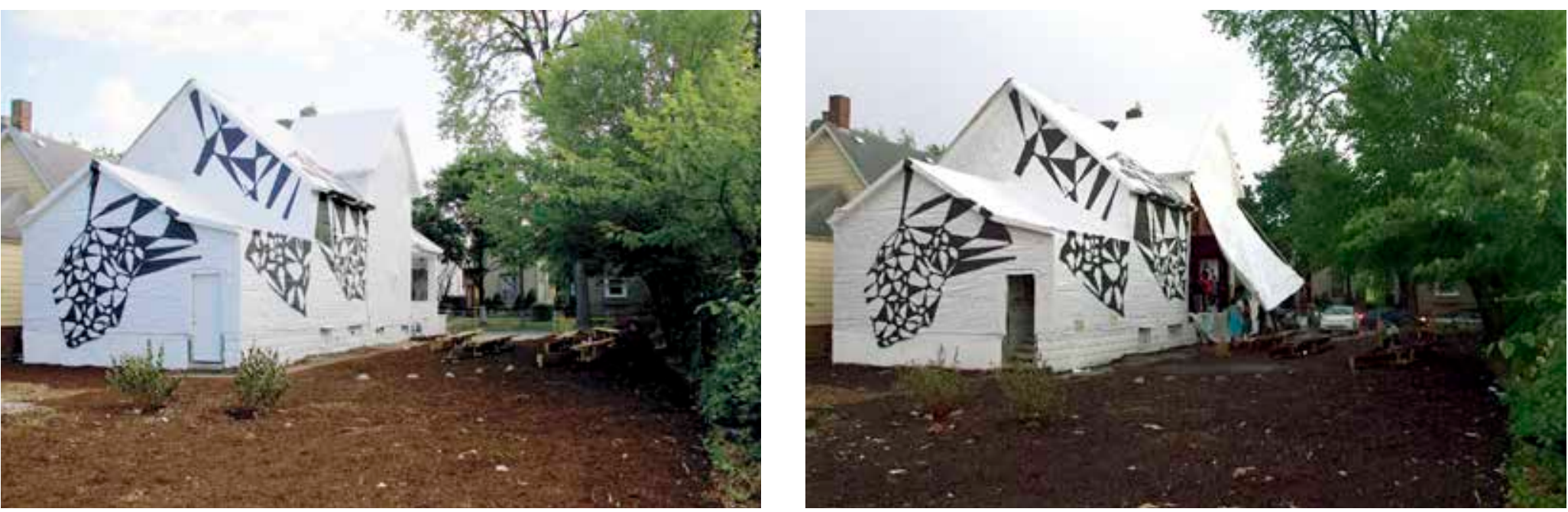

\section{MITCH MCEWEN}

$<$ mitch@anoffice.us>

M.Arch. Master of Architecture, Columbia University GSAPP (USA, 2006). BA in Social Studies / Economics, Harvard College (USA, 2000). She works in architecture and urban design, focused particularly on the intersection of urban culture and global forces. Awarded numerous grants, including Graham Foundation (2014), Knight Foundation award (2015) and New York State Council on the Arts (2011). Selected to the USA Pavilion for the Venice Architecture Biennale (2016), Methexis, Residency exhibition at Museum of Contemporary Art Detroit (MOCAD). Is an Assistant Professor of Architecture at University of Michigan, Taubman College of Architecture and Urban Planning.

\section{MARCELO LÓPEZ-DINARDI}

<marcelo@anoffice.us>

Architect, Master in Critical, Curatorial and Conceptual Practices in Architecture, Columbia University GSAPP (USA, 2013). Bachelor in Architecture from the Polytechnic University of Puerto Rico, 2004, cum laude. He was researcher and production coordinator of House Housing: An Untimely History of Architecture and Real Estate, for the Buell Center of Columbia University exhibited in Venice in 2014, co-edited the book Promiscuous Encounters for GSAPP Books, founding editor of Polimorfo and director of CIUDADLAB, and has been selected to represent the USA Pavilion in the Venice Architecture Biennale in 2016. He is an Adjunct Assistant Professor at Barnard+Columbia Architecture, Columbia University, and Faculty at the New Jersey Institute of Technology.
Presentación de Monstah Black/ Monstah Black performance (c) Marcelo López-Dinardi
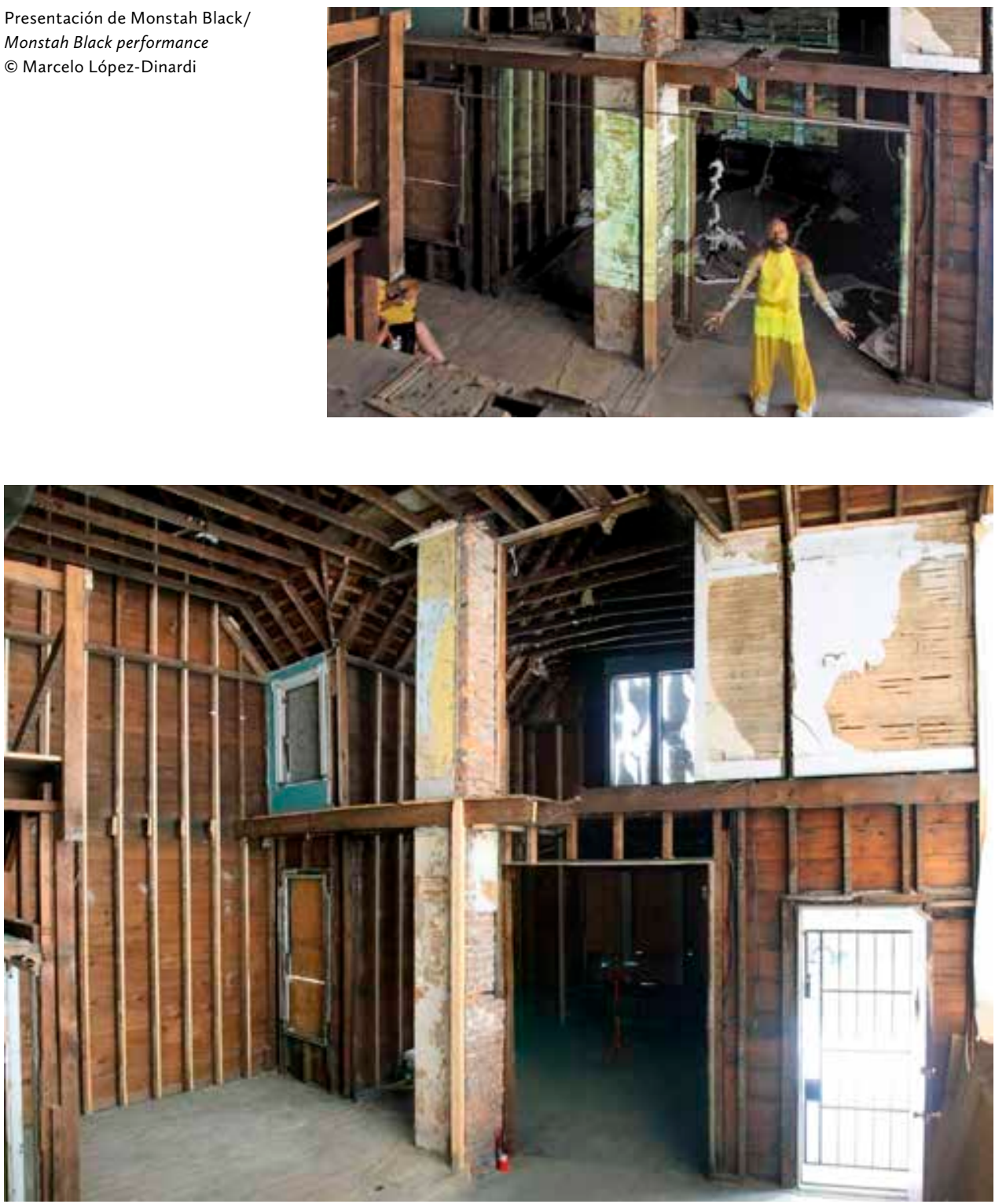

Escenario interior / Interior stage @ Marcelo López-Dinardi 